Pesq. Vet. Bras. 36(10):947-950, outubro 2016 DOI: 10.1590/S0100-736X2016001000005

\title{
Antibodies against Neospora caninum, Sarcocystis spp. and Toxoplasma gondii detected in buffaloes from Rio Grande do Sul, Brazil ${ }^{1}$
}

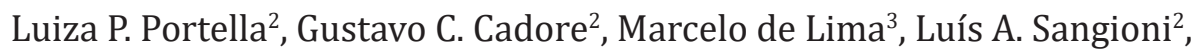 \\ Geferson Fischer ${ }^{3}$ and Fernanda S.F. Vogel ${ }^{2 *}$
}

\begin{abstract}
Portella L.P., Cadore G.C., Lima M., Sangioni L.A., Fischer G. \& Vogel F.S.F. 2016. Antibodies against Neospora caninum, Sarcocystis spp. and Toxoplasma gondii detected in buffaloes from Rio Grande do Sul, Brazil. Pesquisa Veterinária Brasileira 36(10):947-950. Laboratório de Doenças Parasitárias, Departamento de Medicina Veterinária Preventiva, Universidade Federal de Santa Maria, Camobi, Santa Maria, RS 97105-900, Brazil. E-mail: fefevogel@gmail.com

The presence of antibodies against Neospora caninum, Sarcocystis spp. and Toxoplasma gondii was evaluated in buffaloes (Bubalus bubalis) from Rio Grande do Sul state (RS), southern Brazil. Serum samples $(\mathrm{n}=220)$ were analyzed for antibodies by indirect fluorescent antibody test (IFAT). Antibody presence was considered when the titers were equal or higher than 100 for these protozoa. A total of $60.5 \%$ (133/220) buffalo serum samples were positive for at least one of the protozoa evaluated in this study. Antibodies for N. caninum, Sarcocystis spp. and T. gondii were found in 36.4\% (80/220), 25.5\% (56/220) and 16.8\% $(37 / 220)$ of the buffaloes respectively, indicating a higher frequency of $N$. caninum infection ( $\mathrm{p}=0.0133$ ). The IFAT is a suitable method to diagnose N. caninum, Sarcocystis spp. and T. gondii infection in buffaloes for detecting IgG antibodies. This study demonstrates the presence of these three protozoa in buffalo herds in RS, Brazil, which may be source of infection to other animals. The high frequency of animals positive for $N$. caninum is important and could be related to reproductive problems. Additionally, the presence of Sarcocystis spp. and T. gondii in buffaloes can be a possible public health issue.
\end{abstract}

INDEX TERMS: Antibodies, Neospora caninum, Sarcocystis spp., Toxoplasma gondii, IFAT, protozoa, Apicomplexa, Sarcocystidae, Bubalus bubalis, buffaloes, Rio Grande do Sul, Brazil.

RESUMO.- [Anticorpos contra Neospora caninum, Sarcocystis spp. e Toxoplasma gondii detectados em búfalos no Rio Grande do Sul.] A presença de anticorpos contra Neospora caninum, Sarcocystis spp. e Toxoplasma gondii foi avaliada em búfalos (Bubalus bubalis) no estado do Rio Grande do Sul (RS), Região Sul do Brasil. Amostras de soro de 220 bubalinos foi analisada para presença de anticorpos, através de reação de imunofluorescência in-

\footnotetext{
${ }^{1}$ Received on December 2, 2015.

Accepted for publication on June 21, 2016.

${ }^{2}$ Laboratório de Doenças Parasitárias, Departamento de Medicina Veterinária Preventiva (DMVP), Universidade Federal de Santa Maria (UFSM), Santa Maria, RS 97105-900, Brazil. *Corresponding author: fefevogel@ gmail.com

${ }^{3}$ Laboratório de Virologia, Departamento de Veterinária Preventiva (DVP), Universidade Federal de Pelotas (UFPel), Campus Porto, Pelotas, RS 96010-610, Brazil.
}

direta (RIFI). Foram consideradas positivas as amostras que apresentaram títulos de anticorpos maiores ou iguais a 100, para os protozoários estudados. Um total de $60,5 \%$ $(133 / 220)$ das amostras sorológicas dos búfalos foram positivas para pelo menos um dos parasitas pesquisados. Anticorpos para N. caninum, Sarcocystis spp. e T. gondii foram encontrados em $36,4 \%(80 / 220) ; 25,5 \%(56 / 220)$ e $16,8 \%$ $(37 / 220)$ dos búfalos respectivamente, indicando que houve uma maior frequência de infecção de $N$. caninum em relação aos demais protozoários ( $\mathrm{p}=0.0133)$. A RIFI é um método adequado para o diagnóstico sorológico da infecção por N. caninum, Sarcocystis spp. e T. gondii em búfalos. Este estudo demonstrou a presença destes três protozoários em bubalinos no RS, Brasil, que pode ser fonte de infecção para outros animais. A elevada ocorrência de animais positivos para $N$. caninum é importante e pode estar relacionada a problemas reprodutivos. Adicionalmente, a presença de 
Sarcocystis spp. e T. gondii em búfalos, pode significar um possível problema de saúde pública.

TERMOS DE INDEXAÇÃO: Anticorpos, Neospora caninum, Sarcocystis spp., Toxoplasma gondii, RIFI, protozoários, Apicomplexa, Sarcocystidae, Bubalus bubalis, búfalos, Rio Grande do Sul.

\section{INTRODUCTION}

Buffaloes are fairly healthy animals even though live in hot and humid regions that are favorable to the development of illness. They are susceptible to most diseases, specially infectious and parasitic, that similarly affect cattle. However, the effects of these diseases in buffaloes are less deleterious than in bovine (Michelizzi et al. 2010). Sarcocystis spp., Neospora caninum and Toxoplasma gondii are Apicomplexa protozoa that have worldwide distribution and require an intermediate and a definitive host to complete the life cycle and also have been reported in buffaloes (Dubey et al. 1998, Silva et al. 2010, Konrad et al. 2013). Ruminants can be infected by these parasites through ingesting of the sporocysts or sporulated oocysts present in food or water (Dubey \& Lindsay 2006).

Antibodies against N. caninum and T. gondii have been show in buffaloes in various countries, nevertheless in Southern Brazil the evidence of these protozoa are still scarce. Seroprevalence studies for $N$. caninum in buffaloes showed a positivity ranging from $1.5 \%$ to $70.9 \%$ and are described in southeastern and northern region of Brazil (Fujii et al. 2001, Gennari et al. 2005), Argentina (Campero et al. 2007, Konrad et al. 2013), Egypt (Dubey et al. 1998), India (Meenakshi et al. 2007), Vietnam (Huong et al. 1998), and Italy (Guarino et al. 2000). Seroprevalence to T. gondii are described in Brazil (Silva et al. 2010), Argentina (Konrad et al. 2013), Vietnan (Huong et al. 1998), Iran (Navidpour \& Hoghooghi-Rad 1998), and India (Sharma et al. 2008) with the seropositivity ranging from $1.1 \%$ to $25.4 \%$. Studies showing the seroprevalence for Sarcocystis spp. in buffaloes they are rare, but in Argentina Konrad et al. (2013) reported an occurrence of $50.8 \%$ of seropositive animals for this protozoan.

T. gondii and N. caninum are parasites that play important roles as cause of abortions and congenital diseases in ruminants (Uggla \& Buxton 1990, Buxton 2014). Infections by Sarcocystis spp. affect ruminants but are frequently asymptomatic. Buffaloes are intermediate hosts for Sarcocystis fusiformis, Sarcocystis levinei, Sarcocystis dubeyi, Sarcocystis sinensis and Sarcocystis buffalonis (Dubey et al. 2014). Toxoplasmosis and sarcocystosis are important zoonoses transmitted to the humans, beings by ingestion of raw meat from intermediate hosts, including the buffaloes (Fayer 2004, Jones \& Dubey 2010). The aim of this research was to verify the presence of antibodies against $N$. caninum, T. gondii and Sarcocystis spp. in buffaloes from Rio Grande do Sul, Southern Brazil.

\section{MATERIALS AND METHODS}

Blood samples were collected for convenience from 220 healthy buffaloes (Bubalus bubalis) at a slaughterhouse from Pelotas, Rio Grande do Sul, Brazil. The samples were collected between May and July 2014. The buffaloes were of both genders, Mediterranean breed, aging 2 to 8 years and raised on extensive system, and originated from different parts of RS. Blood was centrifuged for 10 minutes at $1000 \mathrm{~g}$ and serum was stored at $-20^{\circ} \mathrm{C}$ until analysis by indirect fluorescence antibody test (IFAT). For detection of antibodies, Sarcocystis neurona (strain SN-37R) merozoites were used as antigen cultivated in CV-1 cells (African Green Monkey kidney cells). Neospora caninum (strain NC-1) and Toxoplasma gondii (strain RH) tachyzoites were maintained in VERO cells (African Green Monkey kidney cells). The cell cultures were maintained in RPMI 1640 culture medium (Invitrogen, Brazil), supplemented with $10 \%$ fetal bovine serum (Nutricell, Brazil) under $5 \% \mathrm{CO} 2$ at $37^{\circ} \mathrm{C}$.

Serum samples were diluted in PBS at 1:100 (Konrad et al. 2013) positive and negative buffalo serum was used as control for all protozoa tested. Commercial fluorescein-labeled anti-bovine IgG(C) (Goat Anti-Bovine IgG FITC ${ }^{\circledR}, 160 \mathrm{~A}$, Southern Biotech, Oxmoor Blvd, Birmingham, USA) was used as the secondary antibody. Slides were observed at 400x magnification under fluorescent microscope (Leica CTR 4000/EBQ 100, Leica Microsystems, Germany). Titers samples equal to 100 were considered positive for all parasites tested (Fig.1).

All data were analyzed using SAS software (SAS Institute Inc., Cary, NC) to statistical analysis. To evaluate the statistical frequencies of infected animals with different protozoa was used chi-square and Fisher exact test with a 95\% confidence.

\section{RESULTS AND DISCUSSION}

Figure 2 shows Neospora caninum, Sarcocystis spp. and Toxoplasma gondii infections detected by IFAT in this study. A total $60.5 \%(133 / 220)$ of the buffalo serum samples were positive for at least one of the tested protozoa. Antibodies to N. caninum, Sarcocystis spp. and to T. gondii were found in $80(36.4 \%), 56(25.5 \%)$ and $37(16.8 \%)$ of the 220 buffaloes respectively, indicating a higher frequency of $N$. caninum infection $(\mathrm{p}=0.0133)$. Infection by the three protozoa was found in $1.4 \%(3 / 220)$ of the animals. However, N. caninum and Sarcocystis spp. were detected in 9.5\% $(21 / 220) ; N$. caninum and T. gondii in $3.2 \%(7 / 220)$; and Sarcocystis spp. and T. gondii $2.7 \%(6 / 220)$. Statistical difference was found in regard to infection of $N$. caninum associated with Sarcocystis spp. compared with other mixed infections $(p=0.006)$. Presence of antibodies against these protozoa suggests that the buffaloes from RS were infected by these agents and they may be an important reservoir of these pathogens.

Generally the difference of seropositive animals is variable, compared to other studies. The lack of standardization in the cut-off point of IFAT as well as the use of different diagnostic techniques complicates comparison with other studies (Dubey 2003). In this study were found antibodies to $N$. caninum in $36.4 \%$ of the serum samples from buffaloes. The prevalence of antibodies against $N$. caninum in buffaloes was variable in the Brazilian regions. In Northern region of Brazil, were found $48.9 \%$ of 4796 buffaloes (Silva et al. 2014), in the Southeastern region of Brazil was found in $64 \%$ of 222 buffaloes (Fujii et al. 2001). Similar results to our study were found in Northeastern Brazil, with seropositivity $35.9 \%$ of 117 buffalo sera (Gondim et al. 2007). $N$. caninum infection has been reported in buffalo fetus which provides evidence of naturally occurring vertical infection (Chryssafidis et al. 2011), and exists reports indicating an 

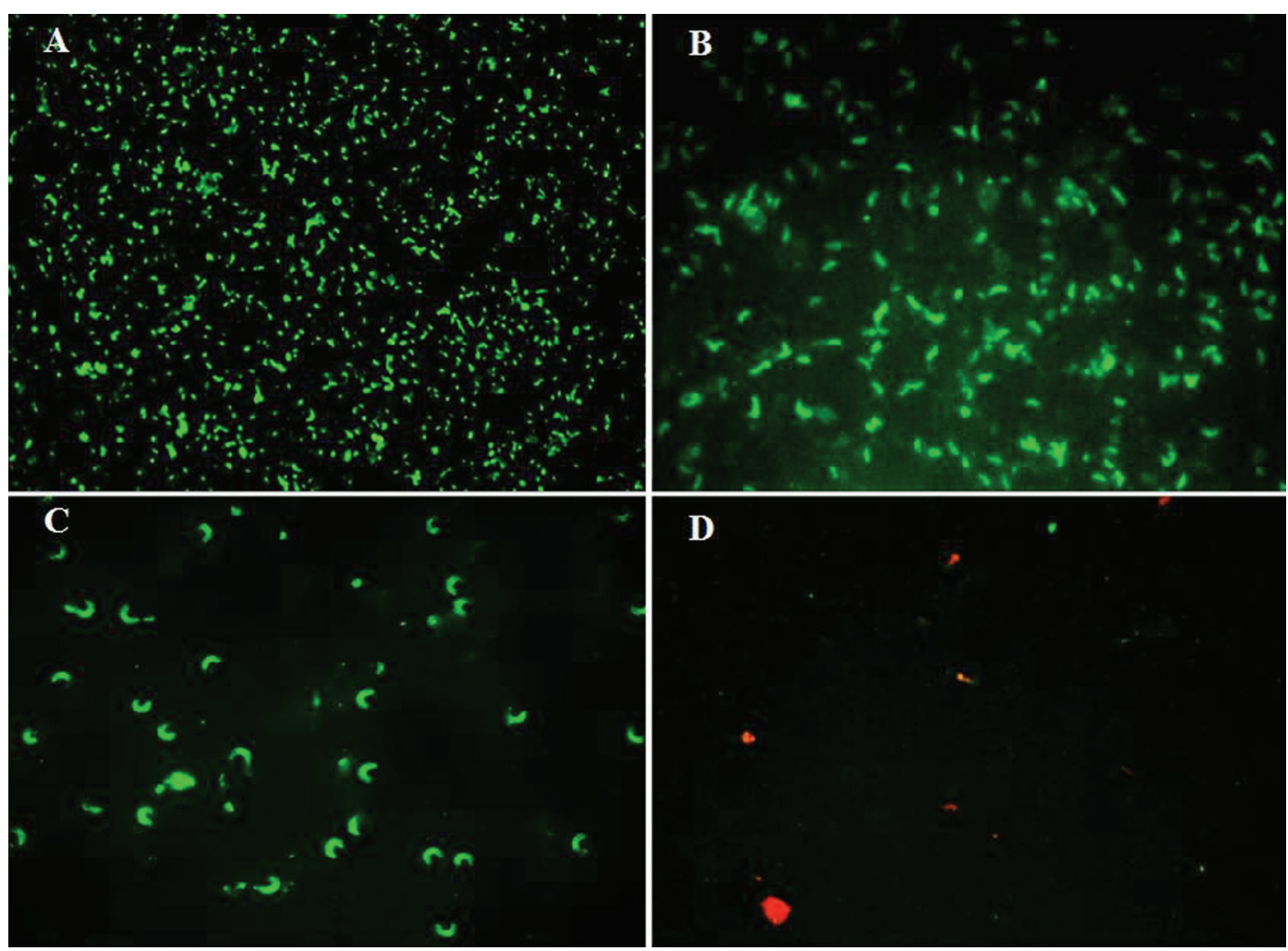

Fig.1. (A) Indirect fluorescence antibody test in buffaloes. Positive titer with tachyzoite of the Neospora caninum. 100x. (B) Positive titer with tachyzoite of the Toxoplasma gondii. 400x. (C) Positive titer with merozoites of Sarcocystis spp. 400x. (D) Negative control with absence of fluorescence. 400x.

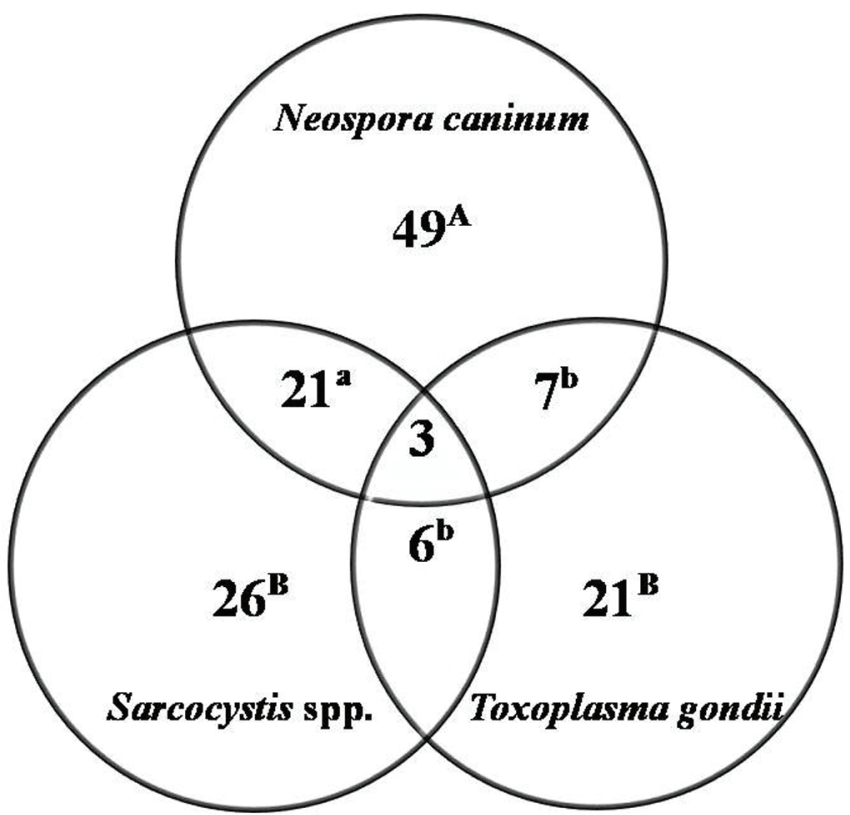

Fig.2. Detection of antibodies against Neospora caninum, Sarcocystis spp. and Toxoplasma gondii, by IFAT, in buffaloes in Rio Grande do Sul, Brazil. Distinct letters indicate statistical differences by Chi-square (capital letters) and Fisher exact test (small letters).

increasing exposure to $N$. caninum infection in buffalo with age (Moore et al. 2014).

Studies evaluating antibody detection of Sarcocystis in buffaloes are rare, and in southern Brazil this is first report of exposure. The seropositivity to Sarcocystis spp. by IFAT found was of $25.5 \%(56 / 220)$. Sarcocystosis is widespread in livestock throughout the world, and most livestock species may harbor these species (Latif et al. 1999). Infection of Sarcocystis spp. in buffaloes have been reported in various countries and detected by different assays. The seroprevalence in Argentina was 50.8\% detected by IFAT (Konrad et al. 2013). In Iran were detected 54.3\% animals positive by ELISA (Ghorbanpoor et al. 2007), from Egypt was verified that $67.6 \%$ and $63.6 \%$ of the serum samples were seropositive to sarcocystosis by ELISA and indirect haemagglutination assay (IHA), respectively (Ashmawy et al. 2014). Furthermore, highest infection rates of Sarcocystis spp. in buffaloes have been reported by using direct examination and histopathology (Oryan et al. 2010, El-Dakhly et al. 2011).

The occurrence of buffaloes positive to T. gondii may indicate a potential risk for the infection of humans. Given that unpasteurized buffalo milk and meat when consumed inadequately cooked from infected animals is a potential source of human toxoplasmosis (Lundén \& Uggla 1992, Dehkordi et al. 2013). In Brazil, States of the Bahia (Gondim et al. 1999), Pará (Silva et al. 2010) and São Paulo (Souza et al. 2001) found that 3.8\% (4/104), 1.1\% (4/374) and $49.9 \%$ (205/411) of the buffaloes had antibodies to T. gondii respectively, lower results compared to $16.8 \%(37 / 220)$ of the buffaloes reported in this study. Similar results were described in Iran with $14.3 \%$ of the buffaloes seropositive to T. gondii (Hamidinejat et al. 2010). The toxoplasmosis transmission occurs often following ingestion of sporulated 
oocysts, or bradyzoites within cysts present in the tissues of numerous food animals (Dubey \& Jones 2008) and products derived from these animals may be infective to man.

\section{CONCLUSIONS}

This study evidences the detection of IgG antibodies against Neospora caninum, Sarcocystis spp. and Toxoplasma gondii in buffalo herds in RS, Brazil.

The high frequency of animals positive for $N$. caninum is important and could be related to reproductive problems.

The presence of Sarcocystis spp. and T. gondii in buffaloes can be a possible public health issue.

\section{REFERENCES}

Ashmawy K.I., Abu-Akkada S.S. \& Ghashir M.B. 2014. Prevalence and molecular characterization of Sarcocystis species in water buffaloes (Bubalus bubalis) in Egypt. Trop. Anim. Health Prod. 46(8):1351-1356.

Buxton D. 2014. Protozoan infections (Toxoplasma gondii, Neospora caninum and Sarcocystis spp.) in sheep and goats: recent advances. Vet. Res. 29:289-310.

Campero C.M., Pérez A., Moore D.P., Crudeli G., Benitez D., Draghi M.G., Cano D., Konrad J.L. \& Odeón A.C. 2007. Occurrence of antibodies against Neospora caninum in water buffaloes (Bubalus bubalis) on four ranches in Corrientes province, Argentina. Vet. Parasitol. 150(1/2):155-158.

Chryssafidis A.L., Soares R.M., Rodrigues A.A.R., Carvalho N.A.T. \& Gennari S.M. 2011. Evidence of congenital transmission of Neospora caninum in naturally infected water buffalo (Bubalus bubalis) fetus from Brazil. Parasitol. Res. 108(3):741-743.

Dehkordi F.S., Borujeni M.R.H., Rahimi E. \& Abdizadeh R. 2013. Detection of Toxoplasma gondii in raw caprine, ovine, buffalo, bovine, and camel milk using cell cultivation, cat bioassay, capture ELISA, and PCR methods in Iran. Foodborne Pathog. Dis. 10(2):120-125.

Dubey J.P., Romand S., Hilali M., Kwok O.C.H. \& Thulliez P. 1998. Seroprevalence of antibodies to Neospora caninum and Toxoplasma gondii in water buffaloes (Bubalus bubalis) from Egypt. Int. J. Parasitol. 28:527-529.

Dubey J.P. 2003. Review of Neospora caninum and neosporosis in animals. Korean J. Parasitol. 41:1-16.

Dubey J.P. \& Lindsay D.S. 2006. Neosporosis, toxoplasmosis, and sarcocystosis in ruminants. Vet. Clin. North Am. Food Anim. Pract. 22(3):645671.

Dubey J.P. \& Jones J.L. 2008. Toxoplasma gondii infection in humans and animals in the United States. Int. J. Parasitol. 38(11):1257-1278.

Dubey J.P., Fayer R., Rosenthal B.M., Calero-Bernal R. \& Uggla A. 2014. Identity of Sarcocystis species of the water buffalo (Bubalus bubalis) and cattle (Bos taurus) and the suppression of Sarcocystis sinensis as a nomen nudum. Vet. Parasitol. 205:1-6.

El-Dakhly K.M., El-Nesr K.A., El-Nahass E.S., Hirata A., Sakai H. \& Yanai T. 2011. Prevalence and distribution patterns of Sarcocystis spp. in buffaloes in Beni-Suef, Egypt. Trop. Anim. Health Prod. 43:1549-1554.

Fayer R. 2004. Sarcocystis spp. in human infections. Clin. Microbiol. Rev. 17(4):894-902.

Fujii T.U., Kasai N., Nishi S.M., Dubey J.P. \& Gennari S.M. 2001. Seroprevalence of Neospora caninum in female water buffaloes (Bubalus bubalis) from the southeastern region of Brazil. Vet. Parasitol. 99(4):331-334.

Gennari S.M., Rodrigues A.A.R., Viana R.B. \& Cardoso E.C. 2005. Occurrence of anti-Neospora caninum antibodies in water buffaloes (Bubalus bubalis) from the Northern region of Brazil. Vet. Parasitol. 134(1/2):169-171.

Ghorbanpoor M., Hamidinejat H., Nabavi L., Khadjeh G.H. \& Jalali M.R. 2007. Evaluation of an ELISA for the diagnosis of sarcocystosis in water buffaloes. Bull. Vet. Inst. Pulawy 51:229-231.
Gondim L.F.P., Souza R.M., Guimarães J. \& Almeida M.A.O. 1999. Frequência de anticorpos contra Neospora caninum em búfalos criados no Estado da Bahia. Proc. 11으 Seminário Brasileiro de Parasitologia Veterinária, Salvador. Colégio Brasileiro de Parasitologia Veterinária.

Gondim L.F.P., Pinheiro A.M. \& Almeida M.A.O. 2007. Frequência de anticorpos anti-Neospora caninum em búfalos (Bubalus bubalis) criados no estado da Bahia. Revta Bras. Saúde Prod. Anim. 8(2):92-96.

Guarino A., Fusco G., Savini G., Di Francesco G. \& Cringoli G. 2000. Neosporosis in water buffalo (Bubalus bubalis) in southern Italy. Vet. Parasitol. 91:15-21.

Hamidinejat H., Ghorbanpour M., Nabavi L., Hajikolaie M.R.H. \& Jalali M.H.R. 2010. Seroprevalence of Toxoplasma gondii in water buffaloes (Bubalus bubalis) in South-West of Iran. Trop. Biomed. 27:275-279.

Huong L.T., Ljungstrom B.L., Iggla A. \& Björkman C. 1998. Prevalence of antibodies to Neospora caninum and Toxoplasma gondii in cattle and water buffaloes in southern Vietnam. Vet. Parasitol. 75:53-57.

Jones J.L. \& Dubey J.P. 2010. Waterborne toxoplasmosis: recent developments. Exp. Parasitol. 124:10-25.

Konrad J.L., Campero L.M., Caspe G.S., Brihuega B., Draghi G., Moore D.P., Crudeli G.A., Venturini M.C. \& Campero C.M. 2013. Detection of antibodies against Brucella abortus, Leptospira spp., and Apicomplexa protozoa in water buffaloes in the Northeast of Argentina. Trop. Anim. Health Prod. 45:1751-1756.

Latif B.M.A., Al-Delemi J.K., Mohammed B.S., Al-Bayati S.M. \& Al-Amiry A.M. 1999. Prevalence of Sarcocystis spp. in meat producing animals in Iraq. Vet. Parasitol. 84:85-90.

Lundén A. \& Uggla A. 1992. Infectivity of Toxoplasma gondii in mutton following curing, smoking, freezing or microwave cooking. Int. J. Food Microbiol. 15(3-4):357-363.

Meenakshi K.S., Sandhu K.S., Ball M.S., Kumar H., Sharma S., Sidhu P.K., Sreekumar C. \& Dubey J.P. 2007. Seroprevalence of Neospora caninum antibodies in cattle and water buffaloes in India. J. Parasitol. 93(6):13741377.

Michelizzi V.N., Dodson M.V., Pan Z., Amaral M.E.J., Michal J.J., McLean D.J., Womack J.E. \& Jiang Z. 2010. Water buffalo genome science comes of age. Int. J. Biol. Sci. 6(4):333-349.

Moore D.P., Konrad J.L., San Martino S., Reichel M.P., Cano D.B., Méndez S., Späth E.J.L., Odeón A.C., Crudeli G. \& Campero C.M. 2014. Neospora caninum serostatus is affected by age and species variables in cohabiting water buffaloes and beef cattle. Vet. Parasitol. 203:259-263.

Navidpour S. \& Hoghooghi-Rad N. 1998. Seroprevalence of anti-Toxoplasma gondii antibodies in buffaloes in Khoozestan province, Iran. Vet. Parasitol. 77:191-194.

Oryan A., Ahmadi N. \& Mousavi S.M.M. 2010. Prevalence, biology, and distribution pattern of Sarcocystis infection in water buffalo (Bubalus bubalis) in Iran. Trop. Anim. Health Prod. 42:1513-1518.

Sharma S., Sandhu K.S., Bal M.S., Kumar H., Verma S. \& Dubey J.P. 2008. Serological survey of antibodies to Toxoplasma gondii in sheep, cattle, and buffaloes in Punjab, India. J. Parasitol. 94(5):1174-1175.

Silva S.P., Mota R.A., Faria E.B., Fernandes E.F.T.S., Souza Neto O.L., Albuquerque P.P.F. \& Dias H.L.T. 2010. Anticorpos IgG anti-Neospora caninum e Toxoplasma gondii em búfalas (Bubalus bubalis) criadas no estado do Pará. Pesq. Vet. Bras. 30(5):443-446.

Silva J.B., Santos P.N., Castro G.N.S., Fonseca A.H. \& Barbosa J.D. 2014. Prevalence survey of selected bovine pathogens in water buffaloes in the north region of Brazil. J. Parasitol. Res. 2014:1-4.

Souza L.M., Nascimento A.A., Furuta P.I., Basso L.M.S., Silveira D.M. \& Costa A.J. 2001. Detecção de anticorpos contra Neospora caninum e Toxoplasma gondii em soro de bubalinos (Bubalus bubalis) no Estado de São Paulo, Brasil. Semina, Ciênc. Agrárias 22:39-48.

Uggla A. \& Buxton D. 1990. Immune responses against Toxoplasma and Sarcocystis infections in ruminants: diagnosis and prospects for vaccination. Rev. Tech. Off. Int. Epiz. 9:441-462. 